Proc. Estonian Acad. Sci. Chem., 2006, 55, 2, 93-100

\title{
Bating of pelts after deliming with peracetic acid
}

\author{
Justa Širvaityte*, Virgilijus Valeika, Kęstutis Beleška, \\ and Violeta Valeikienè \\ Department of Organic Technology, Kaunas University of Technology, Radvilenu pl. 19, \\ LT-50254 Kaunas, Lithuania
}

Received 24 October 2005, in revised form 2 January 2006

\begin{abstract}
The bating of pelts after using peracetic acid for deliming was studied. It was established that the commonly used enzymes, which are active in alkaline media, acted weakly in such pelts: they did not remove scud and hair remnants from the grain of pelt satisfactorily. Enzyme preparations LITHUDAC L and Novo Bate WB, which are active in acid media, can be used for bating such pelts. These enzymes clean the grain of pelt well and do not affect the collagen of pelt markedly.
\end{abstract}

Key words: pelt, bating, acid medium, enzymes.

\section{INTRODUCTION}

Leather manufacturing is one of the most polluting branches of industry. Environmental requirements are continually becoming stricter, and this is the main stimulus to develop new technological solutions to decrease the pollution.

Helsinki convention (HELCOM 199503 15) recommends substituting ammonium compounds for deliming by carbon dioxide and/or weak organic acids [1]. The main problem in the use of ammonium salts for pelt deliming is that when discharged into water these salts stimulate the growth of algae and are poisonous to fish. A large part of ammonium compounds gets as ammonia into the atmosphere and pollutes it.

Considering this recommendation a new deliming method using peracetic acid (PAA) was developed [2]. This method allows high-quality removal of calcium and protects against discharging hydrogen sulphide into the environment.

The problem is that changed deliming techniques change the properties of pelts. Therefore, it has become necessary to improve the bating process.

* Corresponding author, sirvaityte@yahoo.com 
Bating is a short treatment of pelts with an enzyme preparation (EP). The scud residuals, non-proteins, and collagen destruction products are removed during bating. Enzyme activity depends on the bating duration, and the $\mathrm{pH}$ and temperature of the medium. Conventionally, bating is carried out in a deliming solution. Due to this, the establishment of the influence of materials used for deliming on the activity of enzymes is very important.

Most EPs that are suitable for bating act in alkaline media in the presence of ammonia salts. According to our method, the pelt is delimed with PAA at the PAA solution $\mathrm{pH}$ of about 4.0. So, we should use EPs that remain active in this deliming medium.

The aim of this research was to investigate the bating of pelts delimed with PAA and ascertain how the presence of oxidizing materials $\left(\mathrm{PAA}, \mathrm{H}_{2} \mathrm{O}_{2}\right)$ and acid medium influence the activity of enzymes.

\section{EXPERIMENTAL}

For the production of PAA hydrogen peroxide and acetic acid (catalyst $\mathrm{H}_{2} \mathrm{SO}_{4}$ ) were used [3]. The amount of PAA, $\mathrm{H}_{2} \mathrm{O}_{2}$, and acetic acid was determined in the reaction mixture after reaction according to methods presented in the literature [3].

The $\mathrm{pH}$ of the prepared PAA solution was adjusted by using $10 \% \mathrm{NaOH}$ solution. The $\mathrm{pH}$ of a pelt was determined according to the method provided in the literature [4].

The samples for investigation were taken from the lower part of the hide. These hide samples were processed before deliming by the method shown in Table 1, Part A. After liming the pelt was cut into pieces of $5 \times 10 \mathrm{~cm}$, and experimental groups of samples were prepared. The control deliming was carried out by the conventional method shown in Part B of Table 1. The experimental samples were processed under the conditions described in Part C.

The amount of the removed collagen proteins was estimated from the amount of hydroxyproline in the treatment solutions [5]. The amount of the removed non-collagen proteins was calculated as the difference between the total proteins and the collagen proteins in the treatment solutions. The total amount of the proteins was determined by Kjeldahl's method [6].

The activity of EPs was established according to a modified Anson method using casein as substrate [7]. The amount of tyrosine was determined by a spectrophotometer at a wavelength of $274 \mathrm{~nm}$. The shrinkage temperature of the pelts was measured with a special instrument [8].

The microscopical investigation was performed with an Olympus CX 31 microscope. The pelt samples for microscopical investigation were prepared by dehydration with acetone [8]. 
Table 1. Parameters of hide processing

PART A. Processing before deliming

Soaking:

$\mathrm{H}_{2} \mathrm{O}-100 \%$ r.m. (\% of raw hide mass); temperature $-18-21^{\circ} \mathrm{C} ; \mathrm{Na}_{2} \mathrm{CO}_{3}-1.4 \%$ (98\%) r.m; duration $-8.5 \mathrm{~h}$; run - continuous

Washing:

$\mathrm{H}_{2} \mathrm{O}-200 \%$ r.m.; temperature $-20-21{ }^{\circ} \mathrm{C}$; duration - 15 min; run - continuous

Liming:

(a) $\mathrm{H}_{2} \mathrm{O}-100 \%$ r.m.; temperature $-20-21{ }^{\circ} \mathrm{C}$; detergent $-0.1 \%$ r.m.; duration -30 min.; run continuous

(b) $\mathrm{Na}_{2} \mathrm{~S}-2 \%(60 \%)$ r.m.; $\mathrm{Ca}(\mathrm{OH})_{2}-2.3 \%$ r.m.; duration $-1.5 \mathrm{~h}$; run - continuous

(c) $\mathrm{Ca}(\mathrm{OH})_{2}-2.3 \%$ r.m.; duration $-1.0 \mathrm{~h}$; run - continuous

(d) $\mathrm{H}_{2} \mathrm{O}-100 \%$ r.m.; duration - $30 \mathrm{~min}$; run - continuous. Leave stand till morning. Total duration $-24 \mathrm{~h}$

Washing:

$\mathrm{H}_{2} \mathrm{O}-200 \%$ p.m. (\% of pelt mass); temperature $-20-21^{\circ} \mathrm{C}$; duration $-30 \mathrm{~min}$; run - continuous

PART B. Control deliming

Deliming-bating (conventional method):

(a) $\mathrm{H}_{2} \mathrm{O}-40 \%$ p.m.; temperature $-37^{\circ} \mathrm{C} ; \mathrm{NH}_{4}\left(\mathrm{SO}_{4}\right)_{2}-2.2 \%$ p.m.; duration - 30 min; run continuous

(b) $\mathrm{NH}_{4}\left(\mathrm{SO}_{4}\right)_{2}-1.5 \%$ p.m.; duration - 30 min; run - continuous

(c) $\mathrm{H}_{2} \mathrm{O}-100 \%$ p.m.; Oropon $\mathrm{ON} 2-0.15 \%$ p.m.; duration $-1 \mathrm{~h}$; run - continuous. Total duration $-2 \mathrm{~h}$

PART C. Experimental processing

Deliming-bating:

(a) $\mathrm{H}_{2} \mathrm{O}-40 \%$ p.m.; temperature $-37^{\circ} \mathrm{C}$; PAA $-0.75 \%$ p.m.; $\mathrm{pH}$ of PAA solution -4.0 ; duration $-1 \mathrm{~h}$; run - continuous

(b) EP $-0.15 \%$ p.m.; duration $-1 \mathrm{~h}$; run - continuous

In our investigation we used the EPs Novo Bate WB and Novo Bate 160 produced by AS Novozymes, LITHUDAC L by FGL International, and Oropon ON2 by Röhm GmbH \& Co.

\section{RESULTS AND DISCUSSION}

As the developed method includes deliming with PAA, it is very important to know how EPs, which are adapted to alkaline media, will act in an acid medium in the presence of oxidizing materials. Oropon ON2, an EP that is active in neutral and alkaline media (usable for conventional deliming), was chosen for the investigation of bating. The limed pelt samples were delimed under the following conditions:

Group 1 of samples was delimed by the conventional method (Table 1, Part B), using ammonia salts and the EP Oropon ON2 for bating; 
Group 2 - delimed with PAA using the EP Oropon ON2 for bating (conditions presented in Table 1, Part C);

Group 3 - only delimed with PAA (conditions presented in Table 1, Part C). No bating was performed.

Qualitative indexes of pelts were determined after processing. They are presented in Table 2.

As Table 2 shows, the pelt obtained by using PAA (sample groups 2 and 3 ) is less affected than the pelt obtained with ammonia sulphate (sample group 1): a smaller amount of collagenous and non-collagen proteins is removed from the pelt. Comparison of the samples obtained with PAA shows that the EP added for bating (sample group 2) acts on such pelts. More collagenous and non-collagen proteins were removed than from pelt samples that were not treated with EP (sample group 3). These results imply that the activity of the EP used decreases during the treating of a pelt delimed with PAA, but does not disappear completely. After dehydration microscopic investigation of the grain of the pelts was carried out. The micrographs are presented in Fig. 1.

The microscopic investigation confirmed the above-presented results. After conventional deliming and bating (Fig. 1a), the grain of the pelt is clean, the hair roots are opened, and there are no remnants of hair. The samples from groups 2 and 3 are not characterized by clean grains. On the other hand, the hair roots in the grain of the pelt from sample group 2 are slightly opened (Fig. 1b).

The obtained results suggest that the bating of pelts delimed with PAA should be optimized. Optimization could be performed in two ways. Firstly, the amount of a conventional EP, which allows receiving a high quality pelt, can be determined. Secondly, an EP that is active in acid media can be applied. Currently, few such EPs are available for leather processing. These EPs are suitable for bating leather after chrome tanning in an acid medium.

It is very important to know the medium in which the EP will act. It was established that after $1 \mathrm{~h}$ of deliming with PAA under the conditions described in Table 1, Part C, the $\mathrm{pH}$ of the deliming solution was 5.0 and the $\mathrm{pH}$ of the pelt was 5.8. This means that the EP will act on a pelt whose $\mathrm{pH}$ is about 5.8. After $1 \mathrm{~h}$ of deliming, the solution contains $0.3 \% \mathrm{H}_{2} \mathrm{O}_{2}$ and $0.35 \%$ PAA.

Four EPs were chosen for a further experiment: Oropon ON2 and Novo Bate 160, which are active in neutral and alkaline media, and Novo Bate WB and

Table 2. Qualitative indexes of pelts after processing

\begin{tabular}{l|c|c|c|c}
\hline \multirow{2}{*}{$\begin{array}{c}\text { Sample } \\
\text { group }\end{array}$} & \multirow{2}{*}{$\begin{array}{c}\text { The } \mathrm{pH} \\
\text { of pelt }\end{array}$} & \multicolumn{2}{|c|}{$\begin{array}{c}\text { Amount of removed proteins } \\
\text { from pelt, g from kg of pelt }\end{array}$} & \multirow{2}{*}{$\begin{array}{c}\text { Shrinkage } \\
\text { temperature of } \\
\text { pelt, }{ }^{\circ} \mathrm{C}\end{array}$} \\
\cline { 3 - 4 } & & Collagenous & Non-collagen & \\
\hline 1 & 8.07 & 0.085 & - & 65.0 \\
2 & 6.01 & 0.074 & 1.88 & 62.0 \\
3 & 6.09 & 0.056 & 1.41 & 61.5 \\
Limed pelt & 11.27 & - & - & 59.0
\end{tabular}




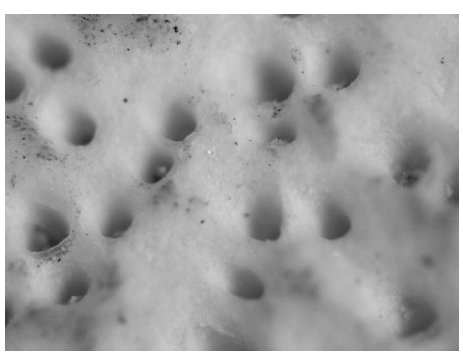

(a)

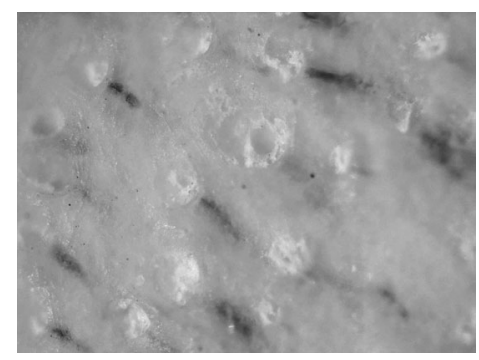

(c)

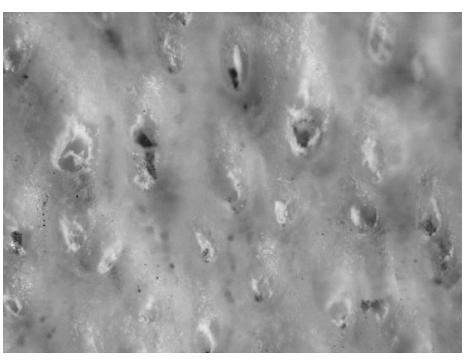

(b)

Fig. 1. Micrographs (magnification $\times 100$ ) of the grain of the pelt: a-delimed using ammonia salts and the EP Oropon ON2 for bating; bdelimed with PAA using the EP Oropon ON2 for bating; c-delimed with PAA (without bating).

Table 3. The dependence of EP activity on the medium $\mathrm{pH}$

\begin{tabular}{c|c|c|c|c}
\hline \multirow{2}{*}{$\begin{array}{c}\text { Medium } \\
\mathrm{pH}\end{array}$} & \multicolumn{4}{|c}{ EP activity, units per g } \\
\cline { 2 - 5 } & Novo Bate WB & LITHUDAC L & Oropon ON2 & Novo Bate 160 \\
\hline 5.5 & 506.70 & 565.30 & 11.04 & 69.6 \\
7.2 & 614.03 & 610.13 & 37.44 & 479.04
\end{tabular}

LITHUDAC L, which are active in acid and neutral media. Firstly, the activity of these EPs at $\mathrm{pH}$ values of 5.5 and 7.2 was determined. These $\mathrm{pH}$ values are suggested in the method for the determination of proteolytic activity. Moreover, $\mathrm{pH} 5.5$ is very close to the $\mathrm{pH}$ of the pelt after $1 \mathrm{~h}$ of deliming. The results are presented in Table 3.

It can be seen that all EPs are active in a weakly alkaline medium. In an acid medium the activity is lower, the activity of LITHUDAC L and Novo Bate WB decreasing slightly and that of Oropon ON2 and Novo Bate 160 decreasing respectively 3.5 and 7 times. Nevertheless, the activity of Novo Bate 160 remains higher than of Oropon ON2.

Next, the bating of pelts using all the mentioned EPs was carried out. The limed pelt was distributed into 6 experimental groups:

Group 1 of samples was delimed by the conventional method (Table 1, Part B), using ammonia salts and the EP Oropon ON2 for bating;

Group 2 - delimed with PAA using the EP Oropon ON2 for bating (conditions presented in Table 1, Part C); 
Group 3 - as 2, but using the EP Novo Bate 160 for bating;

Group 4 - as 2, but using the EP LITHUDAC L for bating;

Group 5 - as 2, but using the EP Novo Bate WB for bating;

Group 6 - as 2, but without bating.

The qualitative indexes of the pelt after processing are presented in Table 4.

The data presented in Table 4 show that pelt collagen was not affected very strongly because the amount of the removed collagenous proteins is inconsiderable in all experimental groups. On the other hand, the value of this index depends on the EP used. The EP Novo Bate WB (sample group 5) affects a pelt more than other EPs. The collagen was affected weakly using the EP Oropon ON2 in an acid medium (sample group 2) and without bating (sample group 6). The amount of the removed non-collagen proteins is different and also depends on the EP used. The largest amounts of non-collagen proteins were removed using the EPs LITHUDAC L and Novo Bate WB (sample groups 4 and 5). The EP Oropon ON2 had a smaller effect. As the largest part of noncollagen proteins consists of scud and hair remnants removed from the grain, a microscopic investigation was carried out. The micrographs are presented in Fig. 2.

It can be seen that in an acid medium the EP Oropon ON2 has a weak effect (Fig. 2c) because part of the scud and hair remnants remain in hair roots. The cleanest grain can be observed in pelts treated using the EPs LITHUDAC L and Novo Bate WB (Fig. 2e and f). The role of EPs is shown by the micrograph in Fig. 2g: without treatment with an EP almost all scud and hair remnants remain on the grain.

In summary, EPs that are conventionally used for bating pelts (i.e., are active in alkaline media) could be used for bating pelts delimed with PAA; however, it is preferable to use EPs active in acid media in such a case. Still, these EPs have not been adopted for pelt bating. This means that their effect not only on pelt indexes but also on qualitative indexes of the produced leather should be established.

Table 4. The influence of processing on qualitative indexes of the pelt

\begin{tabular}{l|c|c|c|c}
\hline \multirow{2}{*}{$\begin{array}{c}\text { Sample } \\
\text { group }\end{array}$} & $\begin{array}{c}\text { Shrinkage } \\
\text { temperature of } \\
\text { pelt, }{ }^{\circ} \mathrm{C}\end{array}$ & \multicolumn{2}{|c|}{$\begin{array}{c}\text { Amount of removed proteins, } \\
\mathrm{g} \text { from kg pelt }\end{array}$} & $\begin{array}{c}\text { The } \mathrm{pH} \\
\text { of pelt } \\
\text { after bating }\end{array}$ \\
\cline { 3 - 4 } & & Collagenous & Non-collagen & \\
\hline 1 & 66.0 & 0.15 & - & 8.13 \\
2 & 62.0 & 0.14 & 2.28 & 5.37 \\
3 & 62.0 & 0.17 & 2.42 & 5.25 \\
4 & 61.0 & 0.16 & 2.83 & 5.26 \\
5 & 61.0 & 0.21 & 3.00 & 5.23 \\
6 & 61.0 & 0.12 & 1.85 & 5.15
\end{tabular}




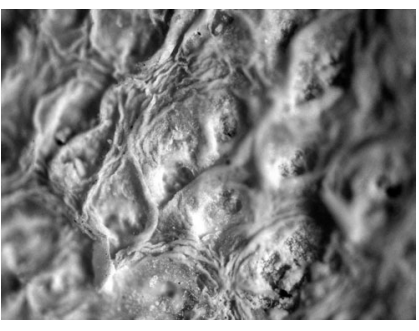

(a)

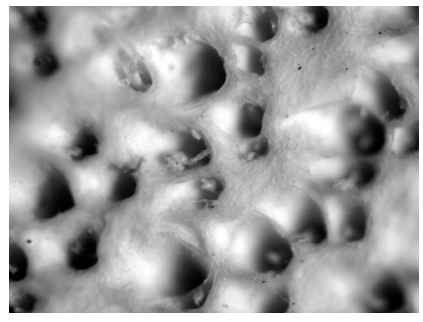

(c)

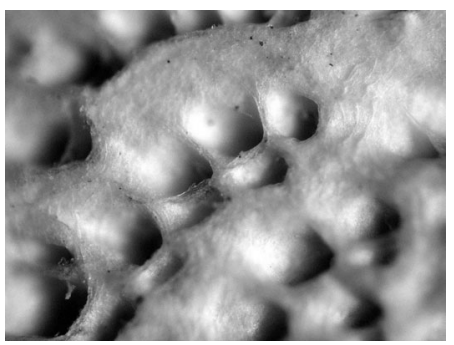

(e)

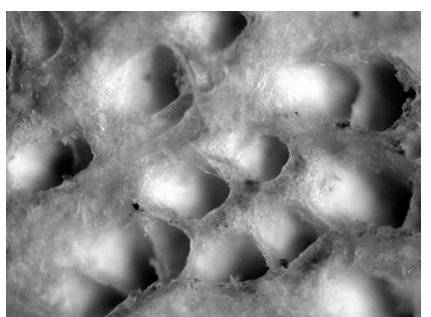

(b)

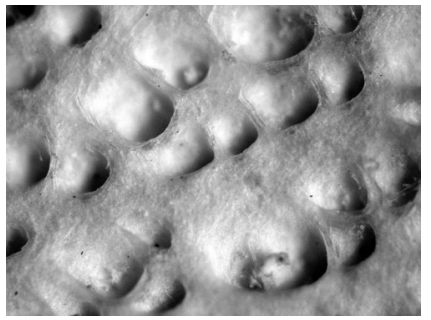

(d)

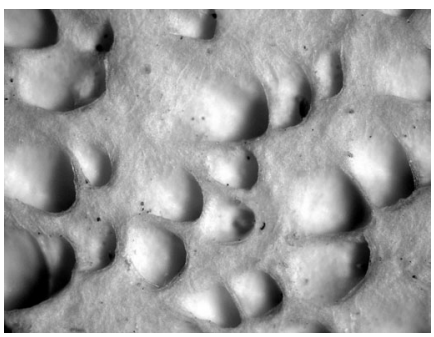

(f)

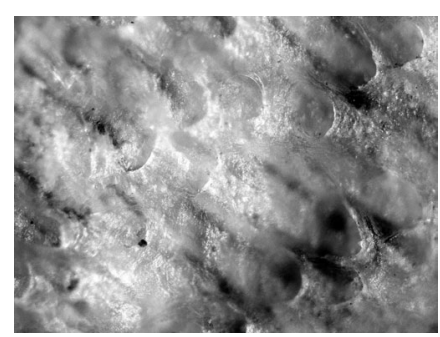

$(\mathrm{g})$

Fig. 2. Micrographs (magnification $\times 100$ ) of the grain of the pelt: $a$ - limed pelt; $b$-delimed using ammonia salts and Oropon ON2 for bating; $\mathrm{c}$ - delimed with PAA using Oropon ON2 for bating; $\mathrm{d}$ - delimed with PAA using Novo Bate 160 for bating; e - delimed with PAA using LITHUDAC L for bating; $\mathrm{f}$ - delimed with PAA using Novo Bate WB for bating; $\mathrm{g}$ - delimed with PAA (without bating). 


\title{
CONCLUSIONS
}

The replacement of conventional deliming with ammonia salts by deliming with peracetic acid requires innovating the bating process. The enzyme preparations that are commonly used for bating in alkaline media act on the pelt delimed with PAA, but the effect is weak: they cannot remove scud and hair remnants from the grain of the pelt well enough. It is preferable to use EPs active in acid media such as LITHUDAC L and Novo Bate WB. The oxidizing materials present in the deliming solution do not block the action of these EPs. They clean the grain of the pelt well and do not affect the collagen of the pelt markedly.

\section{REFERENCES}

1. www.helcom.fi/Recommendation/en_GB/rec17-7/

2. Širvaitytè, J., Peciulyte, L., Valeika, V., Beleška, K., Balciunienè, J. \& Valeikienè, V. Investigation of possibilities of peracetic acid use for deliming of pelt. Chemine technologija, 2005, 35(1), 64-69.

3. Prodesin WP 150: Technischen informationen. Cph Chemie, 1997, 17-18.

4. LST EN ISO 4045:2001. Oda. pH nustatymas.

5. LST ISO 5397:2001. Azoto kiekio ir baltyminès medžiagos nustatymas. Titrimetrinis metodas.

6. Zajdes, A., Mikhajlov, A. \& Pushenko, O. Modified method of hydroxyproline determination. Biokhimiya, 1964, 1, 5-7 (in Russian).

7. GOST 20264.2-74. Enzyme preparations. Methods for determination of proteolytic activity.

8. Golovteeva, A., Kutsidi, D. \& Sankin, L. Laboratory Handbook of Leather and Fur Technology. Moskva, 1982, 309 (in Russian).

\section{Toornaha pehmendamine pärast peräädikhappega töötlemist}

\author{
Justa Širvaitytė, Virgilijus Valeika, Kęstutis Beleška ja Violeta Valeikienè \\ On uuritud toornaha pehmendamist peräädikhappega töötlemise järel. On \\ selgitatud, et tavaliselt kasutatavad ensüümid, mis on aktiivsed leeliseses kesk- \\ konnas, ei eemalda karvade kõrvaldamisel allesjäänud karvajäänuseid. Sellise \\ toornaha pehmendamiseks saab kasutada ensüumpreparaate LITHUDAC L ja \\ Novo Bate WB, mis on aktiivsed happelises keskkonnas. Need ensüumid puhas- \\ tavad naha põhjalikult ega mõju märgatavalt naha kollageenile.
}

